ECONOMIC THEMES (2018) 56(2): 239-252

sciendo

DOI 10.2478/ethemes-2018-0014

\title{
EFFICIENCY ESTIMATION OF COMMERCIAL BANKS BASED ON FINANCIAL PERFORMANCE: INPUT ORIENTED DEA CRS/VRS MODELS
}

\section{Ivana Marjanović}

PhD student at the Faculty of Economics, University of Niš, Republic of Serbia

$\bowtie$ ivana.veselinovic@eknfak.ni.ac.rs

\section{Jelena J. Stanković}

Faculty of Economics, University of Niš, Republic of Serbia

$\bowtie$ jelena.stankovic@eknfak.ni.ac.rs

\section{Žarko Popović}

Faculty of Economics, University of Niš, Republic of Serbia

$\bowtie$ zarko.popovic@eknfak.ni.ac.rs

UDC

347.734:

519.85

Review paper

Received: 29.01.2018 Accepted: 28.05.2018

\begin{abstract}
Measurement and evaluation of the bank's operations efficiency requires analytical techniques that provide data beyond those available from the standard analysis of financial statements. The Data Envelopment Analysis (DEA) is a mathematical programming technique that offers valuable insights in finding inefficient banks taking into account the scope of the services and resources used to provide these banking services. The results of the DEA analysis can provide significant information to the bank's management that can supplement the information obtained using traditional techniques for assessing efficiency. The assessment of banks' efficiency in the Republic of Serbia is of particular importance due to intense competition and implemented banking reforms. Therefore, in this paper DEA analysis will be applied for the examination and assessment of the efficiency of the operations of Serbian banks during the period 2014-2016. The analysis will show which of the banks operates efficiently, where the efficiency of the banks is not at a satisfactory level, as well as the potential reasons for inefficiency.
\end{abstract}

Keywords: Banks, efficiency, Data Envelopment Analysis, ratio analysis

JEL classification: C44, C67, G21 


\section{Introduction}

Serbian banking system became increasingly integrated and more competitive following a process of banking sector reforms, the reorganization of existing and entry of new banks into the banking system of the Republic of Serbia during the two decades preceding to the global credit crisis that started in late 2007. This process resulted in amplified requirements related to the banks' capital and in a stronger emphasis on the significance of efficiency in the banking sector. In order to remain competitive in individual markets, banks must constantly compare themselves with their competitors, recognize the best and strive to learn from. Stability of financial system represents an important determinant of the overall economic growth.

The purpose of banks' efficiency assessment is the separation of those banks that operate inefficiently from those that operate effectively, that is, the identification of best practices. This kind of assessment is done by applying certain type of frontier analysis. The results of stated assessment can be used either (Berger \& Humphrey, 1997): (1) to notify government policy by evaluating the effects of deregulation, mergers, or market structure on efficiency; (2) to conduct a research by describing the efficiency of a business, provide ranking of firms, or check how evaluated efficiency may be related to the various efficiency techniques employed; or (3) to improve management performance by detecting 'best practices' and 'worst practices' related with high and low level of efficiency, correspondingly, wherein the tendency is to achieve the former practices while discouraging the latter.

Today's conditions require regular analyses of the bank's operations and analysis of the whole competitive market in order to develop an appropriate model for efficiency assessment. An adequate analysis of banks' operations and the identification of factors that cause inefficiency can greatly facilitate decisionmaking for managers. In practice, analysis based on financial indicators is often used, however, this approach in modern conditions does not provide a satisfactory amount of information. In order to carefully identify economic reality, in view of its complexity, it is often required to use methods and tools based on statistics, operations research or econometrics (Barburski, 2013). Frontier analysis provides a complete, empirically determined, numerical efficiency assessment and ranking of firms that is not otherwise available (Berger \& Humphrey, 1997). In the recent years one of the most commonly used non-parametric frontier technique for efficiency evaluation of banks is Data Envelopment Analysis.

For that reason the main purpose of this paper is to examine and evaluate the efficiency of Serbian banks over the period 2014-2016 in order to investigate the efficiency dynamics of each of the banks. The analysis will show which of the banks operate efficiently and which of the banks have efficiency that is not at a satisfactory level, as well as the potential reasons of inefficiency. 
Based on the given objective, the paper is structured so that, in addition to the introduction and conclusion, it contains the following components: (1) Literature review and methodology; (2) Characteristics of the banking sector of the Republic of Serbia; (3) Model formulation and analysis of the results.

\section{Literature review and methodology}

In the recent years there has been noted an increased interest of researchers in the determination of the level of efficiency of banks as well as the determinant of obtained efficiency. Consequently, a number of different methods have been applied and the existence of different determinants of bank efficiency has been determined, all in accordance with the purpose of the analysis.

Phan et al. (2016) in their paper examine the relations between bank competition, market concentration and X-efficiency in banking on a sample of six emerging Asian countries. They have determined that market concentration, bank size and gross domestic product growth have positive influence on X-efficiency, while competition and liquidity risk have a negative influence on X-efficiency. Azad et al. (2017) have used two-stage data envelopment analysis to investigate bank efficiency in Malaysia. Their findings show that bank nature, bank ownership and gross domestic product have noteworthy effect on bank efficiency. Gardener et al (2011) and Khan (2015) investigate bank efficiency in Southeast Asian Countries. Spulbăr and Niţoi (2014) investigate bank cost efficiency factors in transition economies. They have applied heteroscedastic stochastic frontier model and found the evidence that banks that follow a more cautious strategy, which reflects in average expectations on profitability and lower risk, have greater cost efficiency. Also, their findings have shown that a greater gross domestic product growth rate indicates an intensification in the inefficiency level, demonstrating an untenable bank management conduct. That kind of behavior reflects in adoption of policies that can cause inefficiency in order to obtain greater market share and to acquire higher bonuses in periods of economic growth. Kao and Liu (2016) examine Taiwanese commercial banks and use a parallel production frontiers methodology for intertemporal efficiency analysis. The results specify that the efficiency of these banks enlarged from 2008 to 2013. The improvements in technology were identified as the main determinant of stated increase. Alqahtani et al. (2017) examine the efficiency of Islamic and conventional banks in the GCC (Gulf Cooperation Council) region for the period of and after the global financial crisis using Data Envelopment Analysis and Stochastic Frontier Analysis. Batir et al. (2017) examine conventional and participation banks in Turkey in order to determine their allocative, technical and cost efficiency using Data Envelopment Analysis. Their findings show that the overall loans have a meaningfully positive influence on bank's efficiency while external variables have a significantly negative influence on bank's efficiency, taking into consideration both types of the banks. On the other hand the banks expenses and loan quality have a 
significantly adverse impact on the conventional banks efficiency, while on the other hand, they have a significantly positive influence on participation banks efficiency. Aiello and Bonanno (2016) evaluate the period 2006-2011 and examine the impact of local market conditions on small mutual-cooperative banks' efficiency. Their findings indicate that efficiency intensifies with demand density and market concentration and declines with the increase of the number of bank branches in local markets. Niţoi and Spulbar (2015) investigate the period from 2005 to 2011 on the sample of six developing countries from Central and Eastern Europe. They use a heteroscedastic stochastic frontier model in order to inspect the differences of commercial banks cost efficiency. The results indicate that the efficiency of commercial banks is positively related to a high macroeconomic stability. However, inefficient banks tend to undertake higher risks. Consequently, banks that have a lower solvency rate, lower liquidity and a greater credit risk are more inefficient than other cautious credit organizations. Yin et al. (2013) apply stochastic frontier analysis over the period 1999-2010 in order to determine the Chinese banks technical efficiency. Sufian and Kamarudin, (2016) investigate determinants of efficiency in the Malaysian banking sector during the period 1999-2008. They use the bootstrap Data Envelopment Analysis method to determine individual banks efficiency. Their finding show that banks from the Asian countries are moderately more efficient compared to foreign banks from other regions and their domestic bank peers. Wanke et al. (2016) determine factors of efficiency in OECD banks. They assess the sample of 128 banks from selected OECD countries during the period 2004 to 2013, and employ various financial criteria that follow the CAMELS rating system with the application of robust TOPSIS approach. Assaf et al. (2013) examine the period from 2002 to 2010 and assess the efficiency and productivity of Turkish banks using a Bayesian stochastic frontier approach. They have shown that Turkish banks obtained positive productivity growth during the observed period, and identified the improvement in technology as the main determinant of achieved growth. On the other hand, efficiency growth was negative during the observed period. Zuhroh et al. (2015) use Stochastic Frontier Analysis in order to determine cost efficiency of Islamic Banks in Indonesia. The findings show that allocative inefficiency was the main determinant of cost inefficiency of Islamic-Banks. Holod and Lewis (2011) offer an alternative Data Envelopment Analysis bank efficiency model. In their model deposits are observed as an intermediate product, therefore their dual role in the bank production process is highlighted. As a result, the overall impact of deposits quantity on bank efficiency depends on the efficiency at both phases of the bank production process. Data Envelopment Analysis can be also used in the assessment of the influence of internet banking on the Romanian banks performance (Stoica, 2015). When it comes to assessing the efficiency of the Serbian banking sector, there are not many papers dealing with this issue. Mihailović (2016) has used one nonparametric (Data Envelopment Analysis) and one parametric method (I-distance) in order to evaluate and rank banks in Serbia according to their efficiency, Savić and 
Radosavljević (2012) use an extended DEA - Window analysis on panel data for the period from 2005 to 2011 in order to assess the efficiency of Serbian banks.

The term Data Envelopment Analysis was firstly introduced by Charnes et al. (1978) grounded on the research of Farrell (1957). DEA is a linear programming technique where the set of best-practice or frontier observations are those for which no other decision making unit or linear combination of units achieves the same or higher level of every output (for the given inputs level) or uses the same or lesser level of every input (for the given outputs level) (Berger \& Humphrey, 1997). A DEA model can be twofold, it can either minimize inputs or maximize outputs. The focus of input orientation is at reduction of the input amounts as much as possible while retaining at least the current output levels, while an output orientation aims at maximizing output levels while retaining at least the same input levels (Savić \& Radosavljević, 2012).

DEA models are widely used as a tool for estimation of efficiency, performance or productivity of homogenous decision making units. These effects can be denoted as the outputs of the decision making units (Halkos \& Salamouris, 2004). Different types of DEA models are known in the literature. However, the two most frequently used ones are the CCR model (after Charnes, Cooper and Rhodes, 1978) and the BCC model (after Banker, Charnes and Cooper, 1984). The treatment of returns-toscale represents the central dissimilarity between the two models (Jemric \& Vujcic, 2002): BCC model permits variable returns-to-scale while CCR model only allows constant returns-to-scale. Efficiency measurement for each decision making unit (DMU) in CCR model is attained as a maximum of a ratio of weighted sum of outputs to weighted sum of inputs. The solution of the following linear programming model provides the efficiency measure for DMU (Jemric \& Vujcic, 2002):

$$
\max _{u} z_{0}=\sum_{r=1}^{s} u_{r} y_{r 0}
$$

subject to:

$$
\begin{gathered}
\sum_{r=1}^{s} u_{r} y_{r j}-\sum_{i=1}^{m} v_{i} x_{i j} \leq 0, j=1,2 \ldots, n \\
\sum_{i=1}^{m} v_{i} x_{i 0}=1 \\
u_{r} \geq 0, r=1,2 \ldots s \\
v_{i} \geq 0, i=1,2 \ldots m
\end{gathered}
$$

where $x_{i j}$ is the perceived input amount of the $\mathrm{i}^{\text {th }}$ type of the $\mathrm{j}^{\text {th }}$ DMU and $y_{r j}$ is the perceived output amount of the $\mathrm{r}^{\text {th }}$ type for the $\mathrm{j}^{\text {th }}$ DMU. For the above stated linear programming model, the dual model can be presented as (Jemric \& Vujcic, 2002):

$$
\min _{\lambda} z_{0}=\theta_{0}
$$

subject to:

$$
\begin{aligned}
& \sum_{j=1}^{n} \lambda_{j} y_{r j} \geq y_{r 0}, r=1,2 \ldots s \\
& \theta_{0} x_{i 0}-\sum_{j=1}^{n} \lambda_{j} x_{i j} \geq 0, i=1,2 \ldots m
\end{aligned}
$$




$$
\lambda_{j} \geq 0, j=1,2 \ldots n
$$

The efficiency score obtained by either primal or dual model represents optimal solution $\theta_{0} *$ (so-called CCR efficiency or technical efficiency) for the specific DMU. DMUs for which $\theta_{0} *=1$ are relatively efficient, while DMUs for which $\theta_{0} *$ is less than 1 are considered to be relatively inefficient.

Variable returns-to-scale can be allowed in the model by adding a convexity condition for $X$, i.e. to include one additional constraint in the prior model (Jemric \& Vujcic, 2002):

$$
\sum_{j=1}^{n} \lambda_{j}=1
$$

The subsequent DEA model is referred as the BCC model. The input-oriented BCC model for the DMUs can be formally presented as (Jemric \& Vujcic, 2002):

$$
\min _{\lambda} z_{0}=\theta_{0}
$$

subject to:

$$
\begin{gathered}
\sum_{j=1}^{n} \lambda_{j} y_{r j} \geq y_{r 0}, r=1,2 \ldots s \\
\theta_{0} x_{i 0}-\sum_{j=1}^{n} \lambda_{j} x_{i j} \geq 0, i=1,2 \ldots m \\
\sum_{j=1}^{n} \lambda_{j}=1 \\
\lambda_{j} \geq 0, j=1,2 \ldots n
\end{gathered}
$$

The obtained values are known as "pure technical efficiency scores", bearing in mind they are attained from a model that permits variable returns-to-scale and hence eliminates the "scale part" from the analysis (Jemric \& Vujcic, 2002). Normally, the obtained CCR efficiency value will not surpass the obtained BCC efficiency value for each DMU.

\section{Characteristics of the banking sector of the Republic of Serbia}

Since 2000 Serbian banking sector has experienced a considerable development with the banking sector reform which has resulted in the reduction of the number of state banks, construction of a competitive banking system, as well as restoration of the trust of the population to the banks.

During the decade preceding the reforms of the banking sector, banks have lost their primary function - mobilization of free funds and their placement in profitable projects. Public confidence in the banking sector was lost due to the inability of the depositors to dispose with their assets, as well as due to bad experiences with several pyramid banks during that decade. Due to hyperinflation, dinar deposits completely lost their value, foreign currency savings were frozen, and loans were available only to a narrow circle of citizens and economy, while payment cards did not exist. 
Banking sector was characterized by a high level of insolvency and insolvency of the largest banks, an extraordinary level of non-performing loans and a low level of real interest-bearing assets, frozen deposited foreign currency savings and low profitability (Jović, 2012). Credit activity was limited, or directed almost entirely to a narrow circle of related parties in the presence of significant political influence, highly concentrated in the absence of an adequate credit risk assessment, which resulted in a significant underestimation of the incurred and potential losses and reserves for their coverage.

The banking system changing process started with the transition of the Serbian economy when the country had approximately 90 banks. Since then, until now (for approximately 15 years) the number of banks was more than halved, so that the current number of banks is the result of revoking operating licenses, rehabilitation measures and administration measures undertaken by the National Bank of Serbia, mergers with other banks and the issuance of new licenses for banks. Ownership transformation of the banking sector was carried out primarily through the process of taking over private or privatizing state-owned banks, with strict criteria for assessing the creditworthiness of investors and also with the disabling of the establishment of a monopoly position.

Banks in Serbia are sovereign in their quest of profit-oriented business activities based on the principles of profitability, solvency and liquidity (Savić \& Radosavljević, 2012). At the end of June 2017, the banking sector of Serbia consisted of 31 banks with work permit, with an organizational network of 1,682 business units (34 business units less compared to the end of the preceding quarter) and 23,575 of employees (223 less compared to the end of the preceding quarter) (Banking sector in Serbia: Report for the 2nd quarter of 2017).

The banking sector is highly liquid and solvent - an indicator of capital adequacy at the end of 2016 was over $19 \%$ and share of capital in total sources is around $20 \%$.

The banking sector of the Republic of Serbia operated profitable in 2017, with a net financial result before taxation in the amount of 34.1 billion dinars, which represents an improvement over the net profit before tax compared to the same period of the previous year (Banking sector in Serbia: Report for the 2nd quarter of 2017). Return on Assets (ROA) at the end of the second quarter of 2017 was $2.11 \%$ (increase by $0.79 \%$ compared to the same period in 2016), while return on equity (ROE) amounted to $10.60 \%$ (growth by $4.11 \%$ compared to the previous year) which means that these indicators are at a satisfactory level.

\section{Model formulation and analysis of the results}

The variables included for the input oriented CRS/VRS models are obtained from the income statements and balance sheets of the Serbian banks in the period 2014-2016. The following variables have been used: total assets (Tasset), interest expenditure 
(InterExp), operating expenditures (OperExp) and number of employees (NumEmp) as inputs, and, interest income (InIncome) and profit before tax (ProfitBT) as outputs. The choice of variables was performed in accordance with the model proposed by Halkos \& Salamouris (2004). Descriptive statistics of the stated variables is presented in the Table 1.

Table 1. Descriptive Statistics

\begin{tabular}{|l|c|c|c|c|c||}
\hline & $\mathrm{N}$ & Minimum & Maximum & Mean & Std. Deviation \\
\hline Tasset & 87 & 1325764.00 & 551415772.00 & 106116245.5517 & 123440928.33067 \\
\hline InterExp & 87 & 847.00 & 7925793.00 & 1475299.4023 & 1685130.35583 \\
\hline OperExp & 87 & 1460.00 & 13894410.00 & 3905778.0115 & 3348018.00634 \\
\hline NumEmp & 87 & 66.00 & 3032.00 & 843.9885 & 765.70321 \\
\hline InIncome & 87 & 45487.00 & 27838612.00 & 5829044.1494 & 6267684.26460 \\
\hline ProfitBT & 87 & .00 & 10781396.00 & 1228736.7011 & 2315878.44943 \\
\hline
\end{tabular}

Source: Authors' calculation

During the process of designing a model it is necessary to examine the correlation between the selected variables. The existence of highly correlated variables in the same input or output group could lower model's discrimination power, therefore, some authors suggest that highly correlated variables should be excluded from the model (Avkiran, 1999). However, some other authors claim that high correlation among variables would not alter the efficiency scores and therefore highly correlated variables should not be excluded from a model (Rhodes \& Southwick, 1993; Charnes et al., 1994). Correlation coefficients on input-output data are given in the Table 2 and they show the existence of highly correlated variables. The obtained coefficients indicate a high level of correlation, however, bearing in mind the non-parametric nature of DEA, as well as the above stated opinions, the results of efficiency analysis will be valid but should be interpreted with caution.

Table 2. Correlation coefficients on input-output data

\begin{tabular}{|c|c|c|c|c|c|c|c|}
\hline & & InterExp & Tasset & NumEmp & OperExp & InIncome & ProfitBT \\
\hline \multirow[t]{2}{*}{ InterExp } & Pearson Correlation & 1 & $.855^{* *}$ & $.790^{* * *}$ & $.795^{* *}$ & $.915^{* *}$ & $.600^{* *}$ \\
\hline & Sig. (2-tailed) & & .000 & .000 & .000 & .000 & .000 \\
\hline \multirow[t]{2}{*}{ Tasset } & Pearson Correlation & $.855^{* *}$ & 1 & $.902^{* *}$ & $.939^{* *}$ & $.979^{* *}$ & $.807^{* *}$ \\
\hline & Sig. (2-tailed) & .000 & & .000 & .000 & .000 & .000 \\
\hline \multirow[t]{2}{*}{ NumEmp } & Pearson Correlation & $.790^{* *}$ & $.902^{* *}$ & 1 & $.949^{* *}$ & $.898^{* *}$ & $.598^{* *}$ \\
\hline & Sig. (2-tailed) & .000 & .000 & & .000 & .000 & .000 \\
\hline \multirow[t]{2}{*}{ OperExp } & Pearson Correlation & $.795^{* *}$ & $.939^{* *}$ & $.949^{* *}$ & 1 & $.926^{* * *}$ & $.683^{* *}$ \\
\hline & Sig. (2-tailed) & .000 & .000 & .000 & & .000 & .000 \\
\hline \multirow[t]{2}{*}{ InIncome } & Pearson Correlation & $.915^{* *}$ & $.979^{* *}$ & $898^{* *}$ & $.926^{* *}$ & 1 & $.792^{* *}$ \\
\hline & Sig. (2-tailed) & .000 & .000 & .000 & .000 & & .000 \\
\hline \multirow[t]{2}{*}{ ProfitBT } & Pearson Correlation & $.600^{* *}$ & $.807^{* *}$ & $.598^{* *}$ & $.683^{* *}$ & $.792^{* *}$ & 1 \\
\hline & Sig. (2-tailed) & .000 & .000 & .000 & .000 & .000 & \\
\hline
\end{tabular}

Source: Authors' calculation 
In the Table 1 descriptive statistics of the variables is presented and shows a large dispersion in data, therefore it is necessary to solve the problem of data imbalance. This problem can be solved by normalization of variables which will create comparable values. The normalization of the data is performed as proposed by Sarkis (2007). Efficiency scores are obtained using the Efficiency Measurement System (EMS) software created by Holger Scheel at University of Dortmund, Germany.

Table 3. Efficiency scores

\begin{tabular}{|c|c|c|c|c|c|c|c|c|c|}
\hline \multirow[t]{2}{*}{ Bank } & \multicolumn{3}{|c|}{2014} & \multicolumn{3}{|c|}{2015} & \multicolumn{3}{|c|}{2016} \\
\hline & VRS & CRS & Scale & VRS & CRS & Scale & VRS & CRS & Scale \\
\hline AIK & 1.00 & 1.00 & 1.00 & 1.00 & 1.00 & 1.00 & 1.00 & 1.00 & 1.00 \\
\hline Alpha & 0.75 & 0.68 & 0.91 & 0.82 & 0.78 & 0.96 & 0.75 & 0.73 & 0.97 \\
\hline Halkbank & 0.73 & 0.73 & 1.00 & 0.73 & 0.71 & 0.97 & 0.81 & 0.79 & 0.98 \\
\hline $\begin{array}{l}\text { Credit } \\
\text { Agricole }\end{array}$ & 0.66 & 0.62 & 0.94 & 0.71 & 0.69 & 0.97 & 0.82 & 0.79 & 0.96 \\
\hline $\mathrm{mts}$ & 1.00 & 1.00 & 1.00 & 0.71 & 0.52 & 0.73 & 0.77 & 0.70 & 0.91 \\
\hline Erste & 0.84 & 0.78 & 0.94 & 0.91 & 0.86 & 0.95 & 0.86 & 0.84 & 0.98 \\
\hline Eurobank & 0.98 & 0.87 & 0.88 & 0.98 & 0.97 & 0.99 & 0.91 & 0.91 & 1.00 \\
\hline Findomestic & 0.81 & 0.78 & 0.95 & 1.00 & 1.00 & 1.00 & 1.00 & 1.00 & 1.00 \\
\hline Addico & 0.73 & 0.71 & 0.98 & 0.71 & 0.70 & 0.99 & 0.70 & 0.68 & 0.97 \\
\hline Intesa & 1.00 & 0.95 & 0.95 & 1.00 & 0.94 & 0.94 & 1.00 & 0.95 & 0.95 \\
\hline JUBMES & 0.86 & 0.63 & 0.74 & 0.96 & 0.72 & 0.75 & 0.96 & 0.71 & 0.74 \\
\hline Jugobanka & 1.00 & 1.00 & 1.00 & 1.00 & 1.00 & 1.00 & 0.96 & 0.87 & 0.90 \\
\hline KBM & 0.63 & 0.56 & 0.89 & 0.61 & 0.58 & 0.95 & 0.66 & 0.54 & 0.82 \\
\hline Komercijalna & 0.86 & 0.78 & 0.90 & 0.79 & 0.75 & 0.95 & 0.82 & 0.79 & 0.96 \\
\hline Marfin & 0.64 & 0.59 & 0.92 & 0.70 & 0.63 & 0.91 & 0.61 & 0.53 & 0.87 \\
\hline NLB & 0.55 & 0.54 & 0.99 & 0.92 & 0.91 & 0.99 & 1.00 & 1.00 & 1.00 \\
\hline Opportunity & 1.00 & 1.00 & 1.00 & 1.00 & 0.99 & 0.99 & 1.00 & 1.00 & 1.00 \\
\hline OTP & 1.00 & 0.91 & 0.91 & 0.98 & 0.92 & 0.94 & 0.87 & 0.84 & 0.96 \\
\hline Piraeus & 0.68 & 0.68 & 1.00 & 0.79 & 0.78 & 0.99 & 0.61 & 0.56 & 0.91 \\
\hline Poštanska & 0.89 & 0.68 & 0.77 & 0.82 & 0.76 & 0.93 & 0.83 & 0.80 & 0.96 \\
\hline Procredit & 1.00 & 1.00 & 1.00 & 0.97 & 0.96 & 0.99 & 0.92 & 0.91 & 0.99 \\
\hline Raiffeisen & 1.00 & 1.00 & 1.00 & 1.00 & 1.00 & 1.00 & 1.00 & 1.00 & 1.00 \\
\hline Sberbank & 0.95 & 0.94 & 0.99 & 0.91 & 0.90 & 0.99 & 0.88 & 0.86 & 0.98 \\
\hline Societe & 1.00 & 0.90 & 0.90 & 0.99 & 0.94 & 0.95 & 0.95 & 0.94 & 0.99 \\
\hline Srpska & 0.70 & 0.62 & 0.89 & 1.00 & 1.00 & 1.00 & 1.00 & 0.83 & 0.83 \\
\hline Telenor & 0.82 & 0.62 & 0.76 & 0.64 & 0.34 & 0.54 & 0.62 & 0.42 & 0.67 \\
\hline Unicredit & 1.00 & 1.00 & 1.00 & 1.00 & 1.00 & 1.00 & 1.00 & 0.98 & 0.98 \\
\hline Vojvođanska & 0.70 & 0.63 & 0.89 & 0.78 & 0.68 & 0.88 & 0.76 & 0.72 & 0.95 \\
\hline VTB & 1.00 & 0.92 & 0.92 & 0.98 & 0.78 & 0.80 & 1.00 & 0.68 & 0.68 \\
\hline Average & 0.85 & 0.80 & 0.93 & 0.88 & 0.82 & 0.93 & 0.86 & 0.81 & 0.93 \\
\hline
\end{tabular}

Source: Authors' calculation

Based on the obtained results, it can be determined that, under the assumption of the VRS 11 banks in 2014 operated effectively, 8 in 2015 and 9 in 2016. Under the assumption of CRS, the number of banks that efficiently operated in 2014 is 7, 6 in 
2015, while 5 banks operated efficiently in 2016. Given the fact that the subject of the analysis was efficiency of 87 banks (29 per year) it can be concluded that more than two thirds of the banks operated inefficiently in the analysed period.

Further, scale scores are analysed. Scale scores are calculated as ratio of technical efficiency (CRS) and pure technical efficiency (VRS). As stated in Thanassoulis (2001), if the pure technical efficiency (VRS) and technical efficiency (CRS) of a DMU are equivalent then scale efficiency is 1 . No adverse influence of scale size on productivity of DMU can be identified. On the other hand, if the DMU has higher VRS efficiency scores compared to CRS efficiency scores then its scale efficiency will be beneath 1 . The higher VRS efficiency ratings compared to CRS efficiency ratings indicate that the DMU is more productive when there is no control of its scale size and less productive when there is a control for scale size (Halkos \& Salamouris, 2004). This leads to the conclusion that there is an influence of scale operation on the efficiency of the DMU. Subsequently, the higher discrepancy between CRS and VRS efficiency ratings will lead to the lower scale efficiency value, which will enhance negative influence of scale size on productivity.

Further on, the results of efficiency for 2016 will be analysed in more detail. As can be seen, several banks (Alpha bank, Halkbank, Credit Agricole, mts, Erste bank, Addico bank, Komercijalna, OTP, Piraeus, Poštanska štedionica and Sberbank) have low efficiency VRS scores (below 0.9) and relatively high scale efficiency (above 0.9). That means that the overall inefficiency of the bank in the CRS model (less than 0.85 ) is attributed mainly to inefficient operations or management.

Additionally, the situation where bank has a completely efficient VRS rating and low scale efficiency value could lead to the conclusion that overall bank's inefficiency occurred due to disadvantageous conditions. Srpska bank represent an example of the stated situation, where its VRS efficiency score is 1 and a scale score is relatively low $(0.83)$. The same holds also for other banks such as Intesa, Unicredit and VTB.

\section{Conclusion}

The question of banks' efficiency plays a significant role in contemporary conditions bearing in mind that performance of financial sector is one of the main determinants of overall economic development of a country. Adequate analysis of efficiency can provide important information to decision-makers in inefficient companies and help them to use their resources efficiently and to improve their performance.

In this paper we have assessed relative efficiency of commercial banks in the Serbian banking market during the period 2014-2016 with the application of Data Envelopment Analysis. The DEA method is one of the potential ways of evaluating the performance of banks that has certain advantages over the traditional method of measuring the efficiency using financial indicators. Compared to traditional 
financial analysis which is based on the financial ratios DEA has several advantages. The main advantage is that DEA gives a comprehensive objective numerical value, ranking, and proposes ways of efficiency enhancement for each one of the inefficient units.

The findings of our study indicate that almost two-thirds of banks operated inefficiently in the observed period, while the main causes of inefficiency were identified inefficient operations or management or disadvantageous conditions. However, our study faces with the limitations regarding existence of highly correlated variables therefore the results of the analysis should be treated with caution.

The paper contributes to the empirical literature in the field of bank's efficiency assessment by providing empirical data regarding efficiency analysis of commercial banks in the Republic of Serbia. The study could be extended in a variety of directions, the most important one being to complement the analysis by extending the sample with the data form years before 2014 and therefore increase the number observations, which could potentially resolve the problem of high correlation among variables. Also, stated extension of sample could provide an opportunity for application of Window DEA analysis.

\section{References}

Aiello, F., \& Bonanno, G. (2016). Bank efficiency and local market conditions. Evidence from Italy. Journal of Economics and Business, 83, 70-90.

Alqahtani, F., Mayes, D. G., \& Brown, K. (2017). Islamic bank efficiency compared to conventional banks during the global crisis in the GCC region. Journal of International Financial Markets, Institutions and Money.

Assaf, A. G., Matousek, R., \& Tsionas, E. G. (2013). Turkish bank efficiency: Bayesian estimation with undesirable outputs. Journal of Banking \& Finance, 37(2), 506-517.

Azad, M. A. K., Munisamy, S., Masum, A. K. M., Saona, P., \& Wanke, P. (2017). Bank efficiency in Malaysia: a use of malmquist meta-frontier analysis. Eurasian Business Review, 7(2), 287-311.

Banker, R. D., Charnes, A., \& Cooper, W. W. (1984). Some models for estimating technical and scale inefficiencies in data envelopment analysis. Management science, 30(9), 1078-1092.

Banking sector in Serbia: Report for the 2nd quarter of 2017, retrieved from https://www.nbs.rs/internet/english/55/55_4/quarter_report_II_17.pdf

Barburski, J. (2013). Measurement of banks' economic efficiency under conditions of imperfect competition. Ekonomski horizonti, 15(1), 3-15.

Batir, T. E., Volkman, D. A., \& Gungor, B. (2017). Determinants of bank efficiency in Turkey: Participation banks versus conventional banks. Borsa Istanbul Review.

Berger, A. N., \& Humphrey, D. B. (1997). Efficiency of financial institutions: International survey and directions for future research. European journal of operational research, 98(2), 175-212. 
Charnes, A., Cooper, W.W., Rhodes, E., (1978). Measuring the Efficiency of Decision Making Units. European Journal of Operational Research 2, 429-444.

Gardener, E., Molyneux, P., \& Nguyen-Linh, H. (2011). Determinants of efficiency in South East Asian banking. The Service Industries Journal, 31(16), 2693-2719.

Halkos, G. E., \&Salamouris, D. S. (2004). Efficiency measurement of the Greek commercial banks with the use of financial ratios: a data envelopment analysis approach. Management accounting research, 15(2), 201-224.

Holod, D., \& Lewis, H. F. (2011). Resolving the deposit dilemma: A new DEA bank efficiency model. Journal of Banking \& Finance, 35(11), 2801-2810.

Jemric, I., \& Vujcic, B. (2002). Efficiency of banks in Croatia: A DEA approach.

Jović, M.E. (2012) Banking sector of Serbia 2001-2011: reforms, recovery and new challenges, Banks and insurance in Serbia 2001-2011, retrieved from http://big.co.rs/upload/Edition/Download/2013-06/Banke_I_Osiguranja_U_Srbiji_ 2001_2011_I_Poredjenje_Sa_Zemljama_Regiona.pdf

Kao, C., \& Liu, S. T. (2016). A parallel production frontiers approach for intertemporal efficiency analysis: The case of Taiwanese commercial banks. European Journal of Operational Research, 255(2), 411-421.

Khan, S. I. M. (2015). Bank Efficiency in Southeast Asian Countries. International Business Management, 9(3), 239-250.

Mihailović, N. (2016). Ranking of banks in Serbia. Yugoslav Journal of Operations Research, 19(2).

Niţoi, M., \& Spulbar, C. (2015). An Examination of Banks’ Cost Efficiency in Central and Eastern Europe. Procedia Economics and Finance, 22, 544-551.

Phan, H. T. M., Daly, K., \& Akhter, S. (2016). Bank efficiency in emerging Asian countries. Research in International Business and Finance, 38, 517-530.

Savić, G., \& Radosavljević, M. (2012). DEA Window Analysis Approach for Measuring the Efficiency of Serbian Banks Based on Panel Data. Management (1820-0222), (65).

Sarkis, J. (2007). Preparing your data for DEA. In Modeling data irregularities and structural complexities in data envelopment analysis (pp. 305-320). Springer US.

Spulbăr, C., \& Niţoi, M. (2014). Determinants of bank cost efficiency in transition economies: evidence for Latin America, Central and Eastern Europe and South-East Asia. Applied Economics, 46(16), 1940-1952.

Stoica, O., Mehdian, S., \& Sargu, A. (2015). The impact of internet banking on the performance of Romanian banks: DEA and PCA approach. Procedia Economics and Finance, 20, 610-622.

Sufian, F., \& Kamarudin, F. (2016). Determinants of efficiency in the malaysian banking sector: Does bank origins matter?. Intellectual Economics, 10(1), 38-54.

Thanassoulis, E. (2001). Introduction to the Theory and Application of Data Envelopment Analysis. Kluwer Academic Publishers

Wanke, P., Azad, M. A. K., \& Barros, C. P. (2016). Efficiency factors in OECD banks: A ten-year analysis. Expert Systems with Applications, 64, 208-227.

Yin, H., Yang, J., \& Mehran, J. (2013). An empirical study of bank efficiency in China after WTO accession. Global Finance Journal, 24(2), 153-170.

Zuhroh, I., Ismail, M., \& Maskie, G. (2015). Cost Efficiency of Islamic Banks in Indonesia-A Stochastic Frontier Analysis. Procedia-Social and Behavioral Sciences, 211, 1122-1131. 


\title{
PROCENA EFIKASNOSTI KOMERCIJALNIH BANAKA ZASNOVANA NA FINANSIJSKIM PERFORMANSAMA: ULAZNO ORJENTISANI DEA CRS/VRS MODELI
}

\begin{abstract}
Apstrakt: Merenje i procena efikasnosti poslovanja banke zahteva analitičke tehnike koje pružaju podatke izvan onih dostupnih iz standardne analize finansijskih izveštaja. Analiza obavijanja podataka (DEA) predstavlja tehniku matematičkog programiranja koja pruža korisne uvide prilikom pronalaženja neefikasnih banaka uzimajući u obzir obim pruženih usluga i resurse koji se koriste za pružanje ovih bankovnih usluga. Rezultati DEA analize mogu pružiti značajne informacije menadžmentu banke koje mogu dopuniti informacije dobijene primenom tradicionalnih tehnika za ocenu efikasnosti.Ocena efikasnosti banaka u Republici Srbiji je od naročitog značaja zbog intenzivne konkurencije i sprovedenih bankarskih reformi. Stoga ce u ovom radu biti primenjena DEA analiza za ispitivanje i procenu efikasnosti poslovanja srpskih banaka tokom perioda 2014-2016 godine. Analiza će pokazati koja od banaka funkcioniše efikasno, kod kojih banaka efikasnost nije na zadovoljavajućem nivou, kao i potencijalne razloge neefikasnosti.
\end{abstract}

Ključne reči: banke, efikasnost, Analiza obavijanja podataka, racio analiza

\section{Authors' biographies}

Ivana Marjanović graduated from the Faculty of Economics, University of Nis in September 2012, the module Accounting, Auditing and Financial Management. She defended her Master's thesis in the scientific field economic statistics, the application of mathematical and statistical methods in economic research. Currently, she is a PhD student at the Faculty of Economics, University of Niš. She was a scholar of the Ministry of Education, Science and Technological Development. Starting from the 2013/2014 school year, she has worked as a demonstrator at Faculty of Economics in Niš. Key areas of her interest include multi-criteria decision-making and optimisation.

Jelena Stanković is an associate professor at the Faculty of Economics, University of Niš for narrow scientific field Economic statistics, the application of mathematical and statistical methods in economic research. She gained the MSc degree at the Faculty of Economics, University of Belgrade and $\mathrm{PhD}$ degree at the Faculty of Economics, University of Niš. In her academic work, she has published two monographs, more than 90 papers in scientific and professional journals and has participated in research conferences at home and abroad. She has been working as a researcher on projects funded by the Ministry of Education, Science and Technological Development of Republic of Serbia, as well as international projects. She participated in numerous seminars and professional training abroad, including specialist training for monitoring and risk analysis in financial institutions organized by FitchRating in 2007 in New York. Key areas of her interest are: quantitative methods in business decision making, methods of 
optimization of business processes and methods of multi-criteria analysis. She is a member of EWG E-CUBE group under Association of European Operational Research Societies, German Operation Research Society (GOR) and Society of Economists of Niš.

Žarko Popović is full professor at the Faculty of Economics in Niš in the field of specialization related to the Mathematics in Economy. He finished his Master degree at the Faculty of Philosophy in Niš, Department of Mathematics, and his $\mathrm{PhD}$ at the Faculty of Science in Niš. Considering his scientific research, he is specialized in the field of semi-group theory, as well as the application of mathematical methods and models in ecology, finance and insurance. Until now, he has published one monograph and five textbooks, as well as many scientific papers in international and national journals with review. From the beginning of his scientific career, he is engaged as researcher in projects financed by the Ministry of Education, Science and Technological Development. He was attending many scientific conferences in country and abroad. He was a mentor to three Master papers. He was the member of the Commission for evaluation of three $\mathrm{PhD}$ dissertations, four MSc thesis and four Master papers. At the Faculty of Economics conducts teaching at all levels of study in mathematical group of subjects. 